Zabytkoznawstwo i Konserwatorstwo XL, Toruń 2011

Katarzyna Wantuch-Jakiewicz

\title{
Złocone ramy do obrazów. Konserwacja i restauracja w zarysie
}

$\mathrm{K}$

onserwacja wymaga od konserwatora wiedzy z zakresu technologii technik złotniczych, co jest równie ważne jak doświadczenie oraz wrażliwość plastyczna; restauracja zaś wymaga jeszcze dobrego smaku. Podejścia naukowe i artystyczne - bez względu na to, czy dotyczą malarstwa, rzeźby czy złoceń - wzajemnie się uzupełniają. Nawet wyznaczenie pewnych stałych w zakresie uzupełniania i rekonstruowania złoconych powierzchni nie porządkuje ich od początku do końca, co byłoby zresztą trudne, bo złocenia zniszczone - a z takimi zwykle styka się konserwator - stają się wielotonowe. Upodabniają się do warstwy malarskiej, z tą różnicą, że oprócz koloru, waloru, mamy tu także do czynienia ze zróżnicowanym połyskiem.

Johann Wolfgang Goethe po zwiedzeniu Galerii Drezdeńskiej pisał: „Przystąpiłem progi tego sanktuarium i zdumienie moje przeszło wszelkie oczekiwanie. Ta wielka kolista sala, w której panowała najgłębsza cisza, odznaczała się przepychem i czystością; błyszczały ramy jeszcze bliższe czasów, gdy je złocono, froterowana posadzka, obszerne przestrzenie, przeznaczone w daleko większym stopniu dla zwiedzających niż do pracy, budziły wzniosłe uczucia, jedyne w swoim rodzaju i wywierały wrażenie, jakie odnosi się wchodząc do kościoła"1. Można by się zastanowić, czy uwaga taka powinna cieszyć muzealników, a tym samym konserwatorów malarstwa i ram. A może rama zauważona jest lepsza od niezauważonej? Dyskusje dotykające spraw estetycznych trwają nieustannie, czy to w odniesieniu do malarstwa, rzeźby poli-

1 J. W. Goethe, Zmyślenia i prawda, cyt. za: Z. Waźbiński, Założenia programowe środkowoeuropejskich galerii malarstwa w XVIII w., „AUNC. Zabytkoznawstwo i Konserwatorstwo" 1979, t. VII, s. 155. 
chromowanej, czy szeroko rozumianych złoceń, w tym też ram. W miarę mijającego czasu zmieniają się argumenty, tak jak zmienia się estetyka czasów, w których żyjemy. Dzieło sztuki nie trwa także w sposób niezmienny i wieczny. W jednych, zmiany wynikające z procesów starzeniowych przebiegają szybciej, w innych wolniej. Dlatego też między innymi nie możemy, według czasem nadmiernie używanego określenia, „przywrócić stanu pierwotnego zabytku”. W postępowaniu konserwatorskim można wydzielić trzy grupy jakości estetycznych:

1. Jakości pierwotne, zamierzone (działanie twórcy oraz naturalne właściwości materiału).

2. Jakości wtórne niezamierzone:

a) spowodowane naturalnymi przemianami tworzywa zmiany chemiczne, korozja, patyna, spękania itp.,

b) uszkodzenia mechaniczne, powstałe w wyniku przypadków najczęściej rozłożonych w czasie.

3. Jakości wtórne zamierzone ${ }^{2}$.

Ocena jakości pierwotnych i wtórnych niezamierzonych jest zależna w dużej mierze od znajomości technik i historii ramy. Jakości wtórne zamierzone będą dwojakiego rodzaju: działanie niefachowe, nieudolne, oceniane negatywnie oraz to poprawne, właściwe. Poprawne i właściwe z punktu widzenia konserwatorskiego nie zawsze również przynoszą zaszczyt wykonawcy, podczas gdy działanie niefachowe czasem mają pewną wartość historyczną oraz estetyczną. Nie należy oceniać krytycznie jakości wtórnych zamierzonych tylko dlatego, że są wtórne, tak jak działania konserwatorskie, jakości wtórne zamierzone i poparte wiedzą fachową oraz świadomością historyczną nie mogą być przyjmowane bezkrytycznie. Najważniejsze aby jakości wtórne zamierzone nie dominowały nad pozostałymi grupami ${ }^{3}$. Należy przy tym mieć na uwadze, zwłaszcza w kontekście konserwacji ramy, fakt nieistnienia dzieła sztuki w oderwaniu od otoczenia; jej przestrzeń wewnętrzna istnieje w kontekście przestrzeni zewnętrznej, którą dla ramy jest zarówno obraz, jak i wnętrze, w którym razem przebywają. Przestrzeń

2 T. Chrzanowski, Problemy estetyczne w konserwacji zabytków ruchomych, "Ochrona Zabytków” 1980, nr 2, s. 166.

3 Ibidem, s. 166. 
wewnętrzna ramy bywa niespójna, nieuporządkowana, w dużej mierze w efekcie końcowym zależna od wiedzy, doświadczenia i twórczej kreacji konserwatora. Jest to poszukiwanie równowagi pomiędzy zabiegami technicznymi a estetycznymi, zakresem rekonstrukcji i rodzajem uzupełnień złoceń, stanem nienaruszonym a kompletnym ${ }^{4}$.

Do zagadnień estetycznych należy zaliczyć prace przy uzupełnieniu ubytków ornamentów, czy to snycerskie, czy też ubytki mas plastycznych. Zależy to nie tylko od biegłości technicznej wykonawcy, ale także od zdolności manualnych i smaku artystycznego.

Nieodpowiednio wykonane uzupełnienie będzie natychmiast zauważalne. Do uzupełniania ubytków struktury używa się drewna sezonowanego lub form oraz żywic sztucznych, np. epoksydowych tj. Araldit HV 241. Ubytki masy można wypełniać masą ramiarską według rozmaitych przepisów, choć są w nich wszystkich elementy stałe: spoiwo -klej glutenowy, olej lniany, żywica, gliceryna w alkoholu - plastyfikuje i stabilizuje klej, papier - celuloza utwardza i plastyfikuje, wypełniacz - kreda szampańska. Z masy można również wykonywać mało skomplikowane odciski.

Do uzupełniania ubytków masy ramiarskiej można też zastosować odlew z kredy bolońskiej i kleju. Spękania na nim uzyskuje się poprzez naniesienie na tkaninę i złamanie. Po tym zabiegu przykleja się spękany sztucznie odlew na miejsce. Podobny efekt można uzyskać na stole próżniowym po wcześniejszym naniesieniu drobnego odlewu na bibułkę japońską. Szlifowanie odbywa się na mokro patyczkami i tkaniną.

Do uzupełnienia ubytków ornamentów, zwłaszcza drobnych, można wykonywać woskowe odlewy z gipsowych form, ale forma musi być zmoczona wcześniej w gorącej wodzie.

Ubytki w formie spękań, często z rozejściem masy ramiarskiej, czasem bardzo szerokie, można zamykać nitkami z Paraloidu B-72 lub bibułką japońską ${ }^{5}$, aby zapobiec odpadaniu.

Dla rozróżnienia uzupełnień ornamentów masą ramiarską polecany jest dodatek siarczanu baru, widocznego przy obserwacji w promie-

4 J. Kubiak, Konserwować czy restaurować?, „Ochrona Zabytków” 1983, nr 1-2, s. 19.

5 Praktyka pracowni konserwatorskiej Rijksmuseum w Amsterdamie. 
niowaniu $\mathrm{X}^{6}$. Inną metodą zaznaczania konserwowanych miejsc w celu szybkiego ich zlokalizowania i tym samym udokumentowania ich położenia jest werniksowanie miejsc uzupełnionych, co można łatwo zidentyfikować w badaniu we fluorescencji UV.

Znalezienie sposobu uzupełnień złoceń wciąż wymaga systematyzacji i tworzenia wyraźnych i czytelnych formuł. Najczęściej są to rozwiązania następujące:

1. Pozostawienie złoceń w stanie zastanym wraz z ubytkami do bolusu, zaprawy, podłoża.

2. Uzupełnienie częściowe koloru podkładu.

3. Uzupełnienie częściowe koloru podkładu oraz scalenie miejsc ubytków złotym proszkiem graficznie kropką lub kreską lub laserunkiem.

4. Uzupełnienie złoceń walorowo, w kolorze zbliżonym do złota oraz otoczenia, czyli koloru podkładu (wersja matowa oraz polerowa$\left.\mathrm{na}^{7}\right)$.

5. Uzupełnienie złoceń walorowo metodą kolorowych kresek, łączących się optycznie w kolor złota wykonanych na złotym płatku.

6. Uzupełnienie i rekonstrukcja całkowita, zacierająca granice ubyt$\mathrm{ku} \mathrm{w}$ technice oryginału.

Oprócz makroskopowych cech odróżnialności podejmowano próby identyfikacji uzupełnień przy pomocy luminoforów - substancji dodawanych do spoiw lub umieszczanych w roztworach wodnych czy alkoholowych bezpośrednio na uzupełnienie imitatorskie ${ }^{8}$.

Wśród zabiegów estetycznych przy powierzchniach złoconych ramy uzupełnianie ubytków pozłoty budzi najwięcej wątpliwości, jest

6 Przepis na uzupełnienia masy ramiarskiej: 20 g kleju króliczego, 70 g perełkowego kleju skórnego, 20 g bielonego oleju lnianego, 50 g sproszkowanej kalafonii, $130 \mathrm{ml}$ wody, 20 g gliceryny, 600 g kredy pozłotniczej, 100 g siarczanu baru. Najpierw rozpuszcza się kalafonię w oleju, kleje glutenowe w wodzie, potem łączy się z połączonymi roztworami kleju i dodaje małą ilość kredy, a następnie dodaje się resztę kredy i siarczan baru. Ibidem, s. 228.

7 Próby takie były podejmowane w Zakładzie Konserwacji Malarstwa i Rzeźby Polichromowanej UMK w Toruniu w latach osiemdziesiątych.

8 Miejsca te mają fioletową fluorescencję, barwnik Blancophor R, pord. G.A.F. Corporation 14 West 51 Street, New York, M. Roznerska, Konserwacja zabytków ruchomych, Warszawa 1973, s. 221. 
najtrudniejsze i wpływa na ostateczny odbiór ramy, a w konsekwencji także obrazu wraz z ramą. Rama bardzo często była i bywa traktowana jako przedmiot użytkowy o małej wartości artystycznej czy materialnej, co odbija się na podejściu do zabiegów estetycznych, które najczęściej polegają na przemalowywaniu brązami czy przezłacaniu płatkami goldmetalu. W praktyce muzealnej ramy rzadko trafiają do pracowni konserwatorskich, a ich konserwacja polega na bieżącym uzupełnianiu drobnych ubytków na galerii. Działania takie często także maskują inne problemy konserwatorskie, takie jak zniszczenie struktury drewna, brak ornamentu czy kawałka listwy. Zakres i metoda uzupełnień powinna być przede wszystkim uzależniona od stanu zachowania złoceń, stanu po oczyszczeniu i próbach przywrócenia połysku płatkom kładzionym na poler. Zdarza się bowiem, że konserwatorzy próbują uzupełniać brudne i zmatowiałe złocenia. Tak jak na innych etapach konserwacji, mamy do wyboru środki tradycyjne i nietradycyjne.

Wielu konserwatorów złoceń przed przystąpieniem do konserwacji po oczyszczeniu z zabrudzeń i przemalowań pokrywa pierwotne złocenia werniksem izolacyjnym, który usuwany jest $\mathrm{z}$ miejsc pulmentowych przed przystąpieniem do uzupełniania ubytków, a pozostawiany w przypadku złoceń olejnych'. Złoty płatek nie podlega degradacji pod wpływem warunków zewnętrznych, chyba że zawiera znaczne dodatki innych metali (miedzi, żelaza i srebra) ${ }^{10}$. Korozji ulega natomiast płatek srebrny, pokrywając się siarczkami czernieje z czasem oraz płatek szlagmetalu, pokrywając się produktami koro-

9 W USA najpopularniejszą izolacje tworzy werniks pod nazwą Soluvar - polinbutyral metakrylanu i Paraloid B-67 rozpuszczone w wolno schnącej benzynie. Werniks ten jest usuwalny łagodnymi rozpuszczalnikami niepolarnymi. Ma to również znaczenie etyczne, gdyż stanowi fizyczną izolację tego, co pierwotne, od tego co dodane przez konserwatora. J. Thorthon, The Use of Nontraditional Gilding methods and Materials in Conservation, w: Gilded Wood, Conservation and History, Madison 1991, s. 217, 222.

10 Złoto niebieskie: $75 \%$ złota i 25\% żelaza, złoto szare: $94 \%$ złota i 6\% żelaza, złoto białe: $75 \%$ złota, $10 \%$ miedzi, $15 \%$ srebra, złoto różowe: $75 \%$ złota i $5 \%$ miedzi, złoto zielone: $75 \%$ złota $25 \%$ srebra. C. Cession, The Surface Layers of Baroque Gildings: Examination, Conservation, Restoration, Cleaninig, w: Cleaning, Retouching and Coatings: Technology and Practice for Easel Paintings and Polychrome Sculpture, IIC, 3-7, September 1990, ed. by J. S. Mill, P. Smith, London 1990, s. 43. 
zji w różnych kolorach od czerwonego poprzez zielony do brązowoczarnego. Z upływem czasu bowiem ulega degradacji powłoka lakieru, który zwyczajowo zabezpiecza płatki. Nie powinno się usuwać oryginalnych werniksów z płatków srebrnych w procesie konserwacji. To samo dotyczy werniksów zabezpieczających złoto, szlagmetal i brązy. Już Saulo pisał, że w restauracji ramy należy wykluczyć użycie „brązy”. Sposób ten, choć ekonomiczny, ma efemeryczną trwałość. Lepiej pozostawić złocenia w stanie zachowania ${ }^{11}$.

Rozedrganie powierzchni, nieporządek złoconych powierzchni ram spowodowane małymi ubytkami zaprawy i złoceń można zadowalająco poprawić poprzez retusz tych miejsc akwarelami. Wystarczy wąska paleta złożona z żółcieni, brązów, czerwieni, czerni. Biel nie jest konieczna przy laserunkowym użyciu farb na białym gruncie. Żółcienie i brązy zwykle spełniają wszelkie potrzeby imitacji złota, a czerwienie i czernie imitują kolor pulmentu. Należy pamiętać, że farby akwarelowe nie są odporne na działanie wody ${ }^{12}$.

Czasem działania imitacji złoceń wymagają wielu zabiegów i połączenia kilku technik. Tak jest w przypadku XIX-wiecznych ram złoconych szlagmetalem lub proszkiem „brązowym”. Gładkie, szerokie śródpasma tych ram po oczyszczeniu z ekskrementów są trudne do scalenia. Uzupełnienia wykonane proszkami metali, w porównaniu z płatkiem, poprzez inny współczynnik odbicia światła od powierzchni, są bardzo widoczne na powierzchni. Działa to niekorzystnie na odbiór estetyczny ramy. Uzupełnienie zniszczonych fragmentów płatkiem szlagmetalu również nie daje zadawalających rezultatów, do najlepszych efektów prowadzi połączenie obu metod.

11 J. Saulo, Dourer sur bois, a l'eau et a la mixtion, reimpression de l'edition de 1876 (edites depuis 1825), Encyclopedie Roret, Paris, s. 18.

12 Na galerii drobne ubytki pozłoty, przy dużym rozrzeźbieniu ramy, można retuszować farbami wodnymi (wcześniej izolacja Paraloidem B-72, retusz pigmenty ziemne + Paraloid lub szelak, na całość wosk). A. Gallone Galassi, P. Fumagalli, E. Gritti, Conservation and Scientific Examination of the Northern Italian gilded.and Painted Altarpieces of the Sixteenth Century, w: Gilded Wood, s. 193. 
Oprócz metod tradycyjnych mamy dziś do wyboru wiele produktów syntetycznych ${ }^{13}$, które w rękach znającego techniki historyczne konserwatora, ze względu na swoją różnorodność, mogą być ciekawą alternatywą i lepiej dostosują się do stanu zachowania złoceń. Korzyścią systemu jest możliwość pracy w niskich temperaturach bez żmudnego procesu przygotowywania kredowego podłoża, a także możliwość polerowania szlagmetalu. Wady systemu powielają w zasadzie wady tradycyjnego złocenia w technice klejowej, połyskowej, czyli wrażliwość na rozpuszczalniki polarne, a także na detergenty. Powłoki nie są także wodoszczelne, co akurat zbliża tę technikę do tradycyjnej. System jest odwracalny acetonem. Wadą techniki syntetycznych pulmentów jest to, że przy mocnym polerowaniu płatek może odpadać i jest słabiej związany z podłożem niż w technice tradycyjnej czy przy złoceniu na polialkohol. Alternatywą dla techniki brązu polerowanego ${ }^{14}$ jestzłoto mineralne złoceń matowych ${ }^{15}$, czyli mika barwiona cienką powłoką metali. Zwykle są to tlenki tytanu i żelaza. Mają niski połysk, czy to użyte jako proszek na mikstionie, czy ze spoiwem. Są też słabo kryjące. Obiecujące efekty daje mieszanie złota prawdziwego w proszku ze złotem mineralnym ${ }^{16}$.

13 Grunty polerskie, spoiwo - eter celulozy, System Kölner, Conasol - spoiwo - polioctan winylu. J. Thorthon, The Use of Nontraditional Gilding methods and Materials in Conservation, s. 226.

Ok. 1920 r. popularne były złocenia na tzw. brąz polerowany (rzymskie złocenie, brąza w kleju glutenowym lub spoiwie gumowym, polerowane poprzez kartkę papieru). A. Gallone Galassi, P. Fumagalli, E. Gritti, Conservation and Scientific Examination of the Northern Italian gilded and Painted Altarpieces of the Sixteenth Century, s. 193.

14 Po konserwacji taka rama powinna być zabezpieczona benotriazolem w etanolu i werniksem z Paraloidu B-44.

15 J. Saulo, Dourer sur bois, a l'eau et a la mixtion, \& 62, s. 20 (tłum. E. Szmit-Naud).

16 A. Łojkuć-Clep, „Złoto mineralne - zastosowanie w konserwatorskich pracach pozłotniczych", praca magisterska napisana pod kierunkiem prof. dr M. Roznerskiej, ZKMiRzP, Toruń, 2000. We wnioskach autorka stwierdza, iż połyskliwe pigmenty mineralne zaliczają się do jednych z najbardziej odpornych materiałów stosowanych w pracach konserwatorskich i restauratorskich. Perłowy, a nie metaliczny połysk oraz słaba siła krycia ogranicza jednakże zakres użycia w pracach restauratorskich pozłoty, tak jak i proszków metali, wyróżniając się znacznie przy foliach metali z racji innego odbicia i załamania padającego światła. Lepiej udaje się efekt scalenia przy powierzchniach złoconych zniszczonych i przy łączeniu złota mineralnego z pigmentami suchy- 
Saulo - zajmujący się wyrobem ram - w swoim traktacie ${ }^{17}$ pisze, że nowe złocenia wymagają nadania im tonu starości, aby dobrze współgrały z całą ramą i obrazem. Zaznacza jednak, że jest to kwestia gustu. Watin uznaje odchody much i nieumiejętne ich oczyszczanie za główny powód zniszczenia złoceń. Aby tego uniknąć, radzi nowe ramy werniksować werniksem kopalowym, damarowym lub pokostem lnianym.

$\mathrm{Z}$ pewnością, jak to podają źródła, złoto kiedyś było pokrywane powłokami, często barwionymi pigmentami czy barwnikami. Dziś także po pokryciu powierzchni oryginalnej i rekonstruowanej werniksem można, zgodnie z technikami pierwotnymi, bądź też dla nadania uzupełnieniom odpowiedniego połysku czy tonu, powłokę powlec podbarwionym werniksem o innej niż werniks rozpuszczalności.

Złocenia zdecydowanie powinno pokrywać się powłokami. $\mathrm{Z}$ jednej strony są to powłoki chroniące je przed mechanicznym uszkodzeniem, ścieraniem, z drugiej chroniące płatki złota niższej próby, a zwłaszcza płatki szlagmetalu, srebra, przed korozją. W przypadku występowania tzw. goldlaków, czyli lakierów złocistych na foliach białych, powłoka ochronna będzie chronić organiczne barwniki przed zmianą koloru. Do tego celu stosuje się żywice syntetyczne akrylowe z dodatkiem barwników oraz filtrów $U^{18}$. Obok szelaku równie szczelne są powłoki z sandaraku. Najbezpieczniej jednak zwłaszcza na folie srebr-

mi w różnych spoiwach oraz z gotowymi farbami. Do technik polerowanych sprawdza się dobrze, a najlepiej w połączeniu z prawdziwym złotem proszkowym. Dużą zaletą tego materiału jest również fakt, iż można go stosować zarówno w technice połyskowej, na poler, jak i matowej, na mikstion.

17 J. Saulo, Dourer sur bois, a l'eau et a la mixtion, s. 19.

18 M. Stachurska, „Zabezpieczenie złoceń wykonanych przy użyciu szlagmetalu”, praca magisterska napisana pod kierunkiem dr. hab. J. Ciabacha, ZKMiRzP, Toruń 1998. Autorka określiła także i zbadała właściwości fizyko-chemiczne dwóch lakierów pozłotnicznych V B-67 i VB-82, czyli werniksów na bazie Paraloidu B-67 i B-82 z dodatkami kompleksowych barwników i fotostabilizatorów z grupy amin z zawadą przestrzenną - Haals. Badała ich podstawowe właściwości fizyczne, takie jak czas schnięcia, elastyczność, ochrona przed szkodliwym wpływem SO2, porowatość, gęstość. We wnioskach końcowych autorka stwierdza, że badane werniksy V B-82 i V B-67dobrze zabezpieczają folie szlagmetalu przed szkodliwym wpływem czynników atmosferycznych, a także przez dodatek barwników dobrze imitują powłokę szelaku. Oba werniksy są odporne na zmiany barwne. Lakier B 82 jest bardziej elastyczny od V B 67, za to ten ostatni jest mniej trwały. 
ne i goldlaki stosować system mieszany, żywic naturalnych i syntetycznych ${ }^{19}$, a wśród nich Paraloid B-44 o udowodnionej skuteczności.

Zanim powszechne stało się stosowanie żywic polimerowych do powłokowania, stosowano $\mathrm{w}$ meblarstwie, ramiarstwie, ale i złoconej snycerce szelak. Używany jest od XVII wieku do wyrobu i konserwacji mebli, do uzupełnienia ubytków bądź do powłokowania. Przez jednych oceniany krytycznie za zmianę barwy i rozpuszczalności w wyniku starzenia, przez drugich ceniony za dobre parametry szczelności dla par i gazów, a także dobrą przyczepność do folii metali. Jednocześnie ma małą odporność na wilgoć, która powoduje jego zmętnienie. Stan zachowania szelaku zależy od warunków przechowywania, jeśli jest ciepło i wilgotno, to następuje szybsza degradacja. Szczególnie niestabilny jest szelak bielony (pozostałości chloru użytego przy bieleniu). Z uwagi na to krótki też powinien być czas przechowywania roztworów alkoholowych (około 10-12 tygodni), a przy przygotowaniu należy unikać ciepła, gdyż indukuje ono reakcje sieciowania ${ }^{20}$.

Wrażenie świeżości nowo wykonanych złoceń zbyt mocno je wyróżnia. Duże partie rekonstrukcji złoceń, jeśli istnieje taka potrzeba, można „spatynować”, czyli nadać stary wygląd - zetrzeć (watą stalową, włóknami szklanymi) lub pokryć powłoką tonującą (wosk biały lub barwiony pigmentami ziemnymi, ormolu ${ }^{21}$, szelak z barwnikami Orasol ${ }^{22}$, Paraloid B-72 z barwnikami Savynil ${ }^{23}$ ).

19 Sandarak w rozpuszczony w alkoholu n-butylowym. Paraloid B-72 w etanolu bądź w 1-metoksy -2 - propanolu, sandarak w rozpuszczony w alkoholu n-butylowym, J. Stachera, Werniksy i lakiery barwne do ochrony powierzchni posrebrzanych, „Biuletyn Informacyjny Konserwatorów Dzieł Sztuki” 2004, nr 3-4, s. 21.

20 Żywica zbudowana jest z niskocząsteczkowych polimerów, a te skomponowane są z monomerów kwasu polihydroksy karboksylowego. Naturalna zawartość wosku w szelaku, z uwagi na jej nierozpuszczlaność w alkoholach, może powodować zmętnienie powłoki. H. Mcgowan-Jackson, Shellac in Conservation, „AICCM Bulletin” 1992, Vol. 18, s. 29-30.

21 W wersji XIX-wiecznego brązu, lakier oranżowy, szelak, alkohol etylowy i metylowy - w XIX wieku były tak robione doskonałe matowe powierzchnie.

22 M. Sawicki, Picture frame conservation or ...repairing?, „AICCM Bulletin” 1995, nr 2, s. 23.

23 C. Cession, The Surface Layers of Baroque Gildings, s. 43. 
Są ramy, które wymagają minimum interwencji. Tak jak w innych dziedzinach konserwatorskich, sztuką jest znalezienie równowagi pomiędzy zakresem działań technicznych i estetycznych. Bardzo ważne jest, aby konserwację obrazu przeprowadzać w nawiązaniu do stanu zachowania i zakresu prac związanych np. ze stopniem oczyszczenia czy rekonstrukcji. 


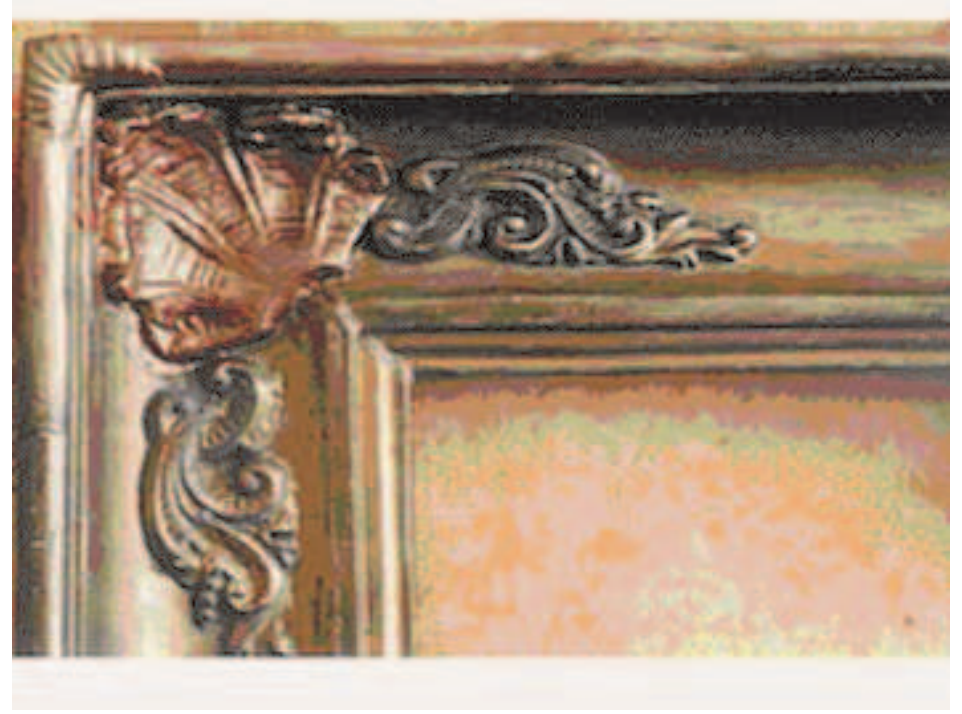

Fot. 1. Nieodpowiednie uzupełnienie ubytku ornamentu (fot. K. Wantuch-Jarkiewicz)

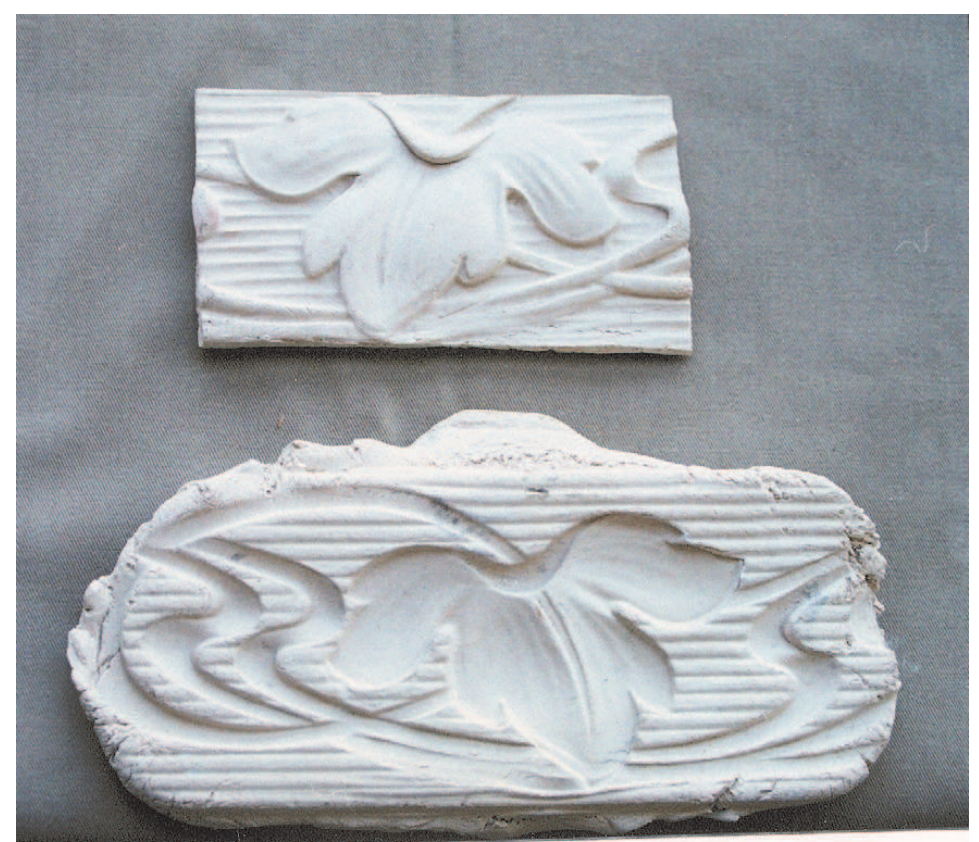

Fot. 2. Negatyw i pozytyw ornamentu wykonany w masie ramiarskiej (fot. K. Wantuch-Jarkiewicz) 


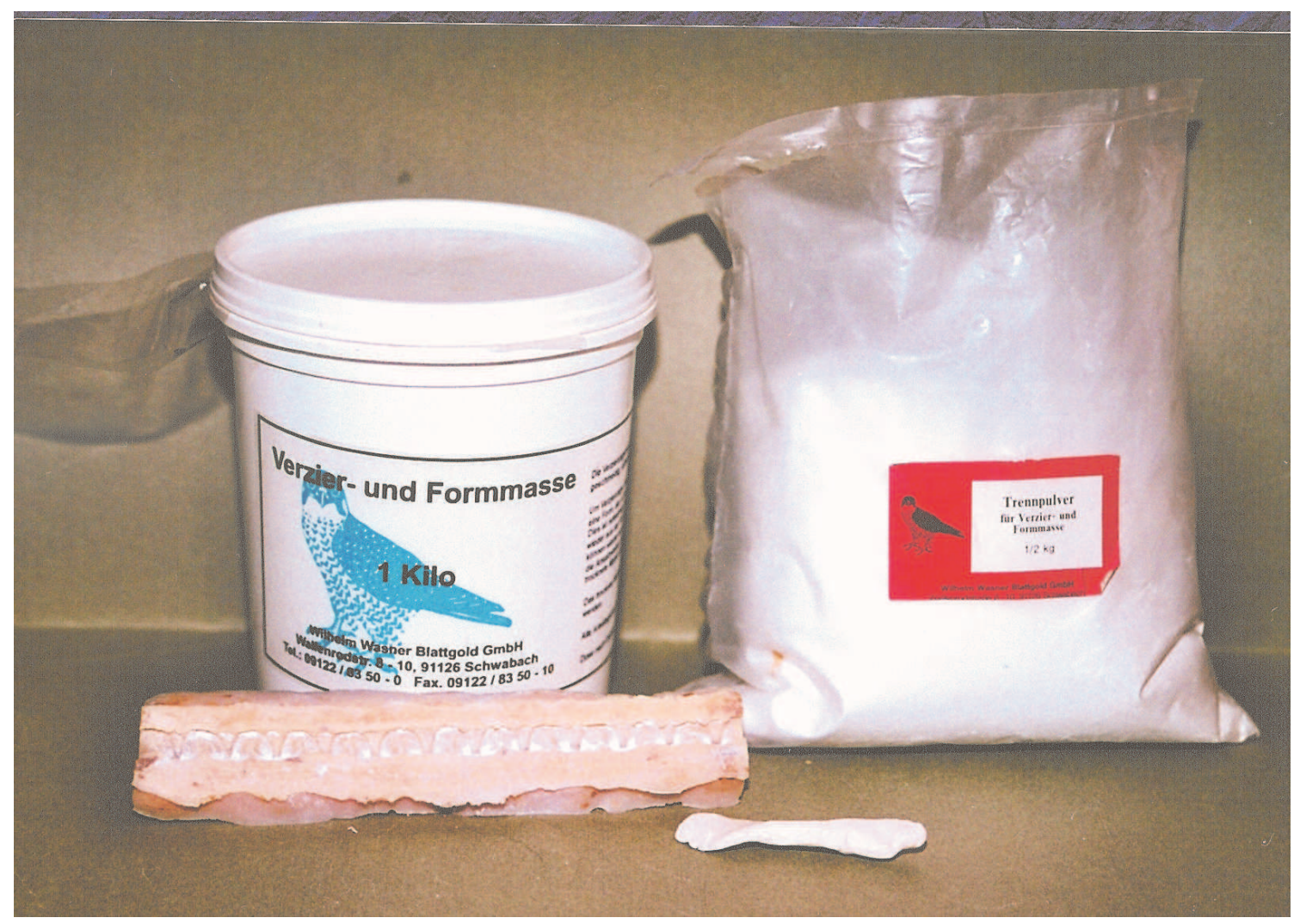

Fot. 3. Współczesny gotowy materiał o właściwościach masy ramiarskiej (fot. K. Wantuch-Jarkiewicz)
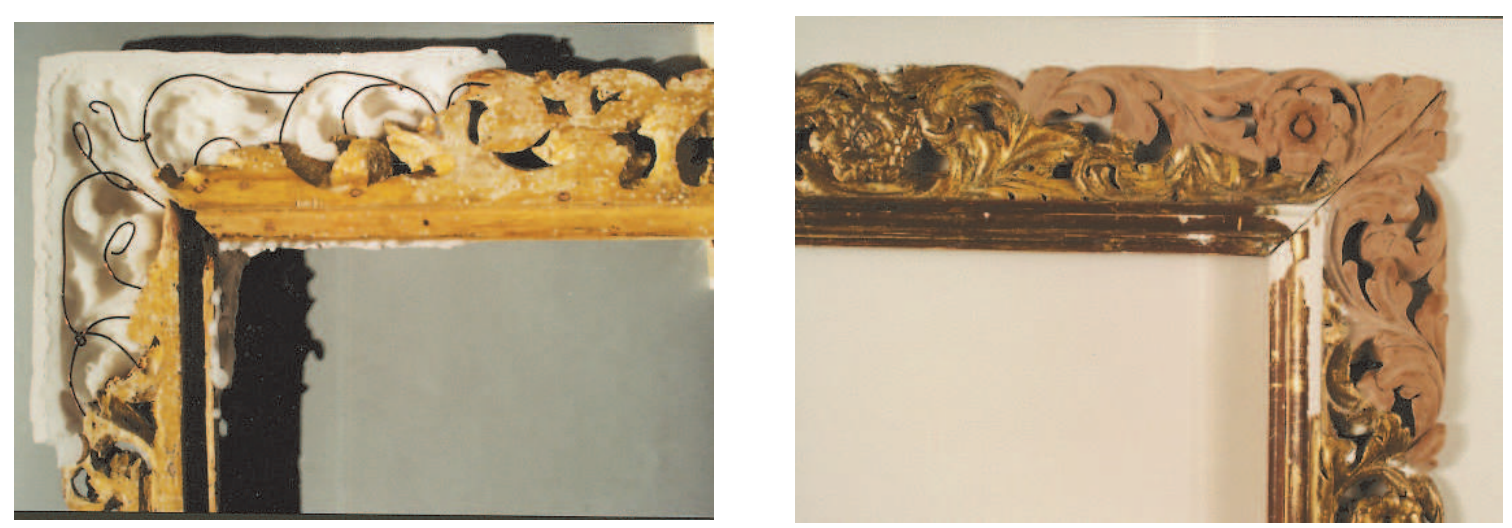

Fot. 4a-b. Forma silikonowa zdjęta z opracowanego wcześniej w plastelinie modelu oraz konstrukcja wzmacniająca odcisk. Odcisk wykonany w żywicy epoksydowej Araldit HV 241 (fot. L. Tymińska) 


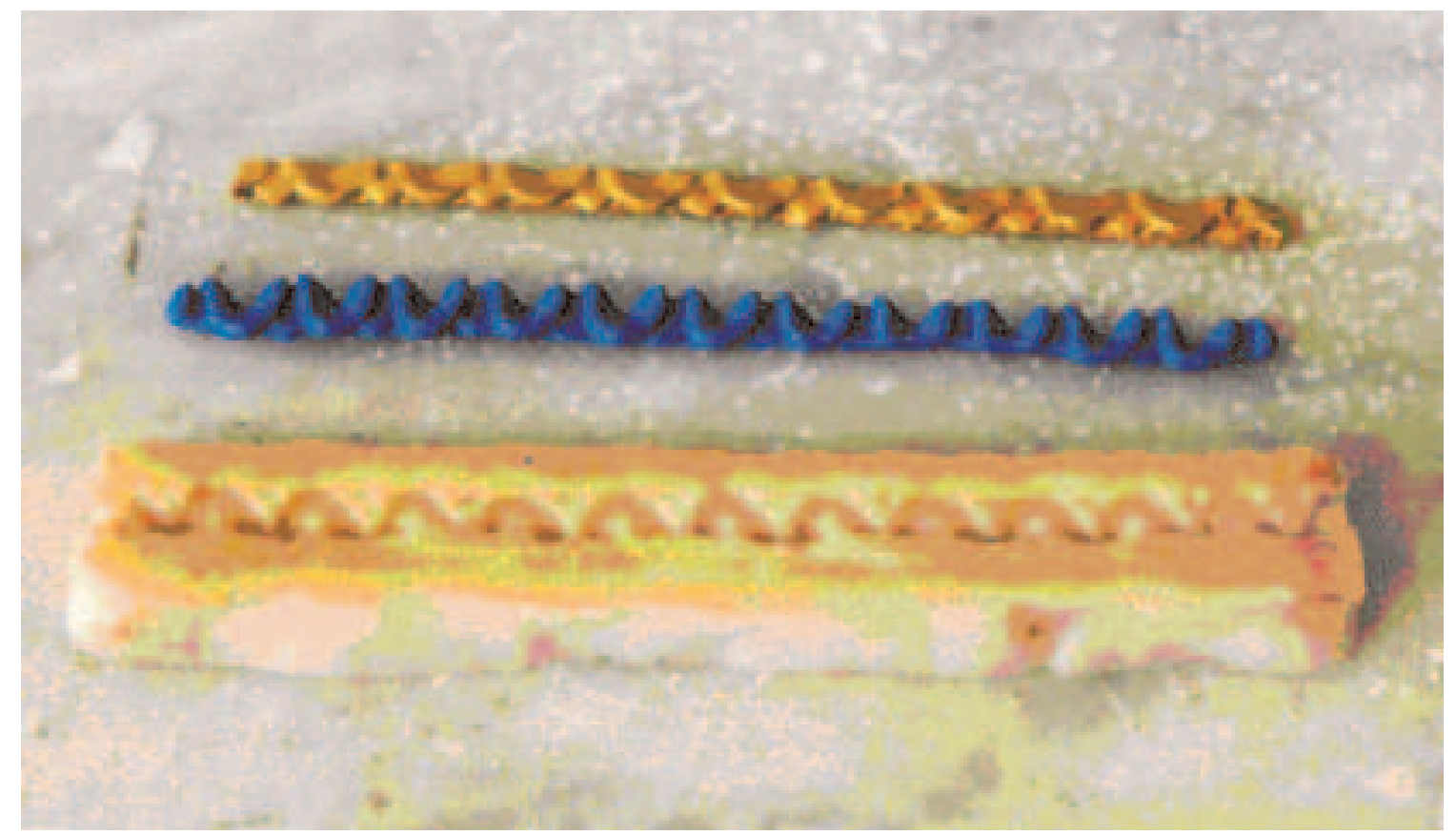

Fot. 5. Forma silikonowa i odciski z wosku oraz żywicy epoksydowej Araldite HV 24; jeden pokryty złotem mineralnym w technice olejnej (fot. K. Wantuch-Jarkiewicz)

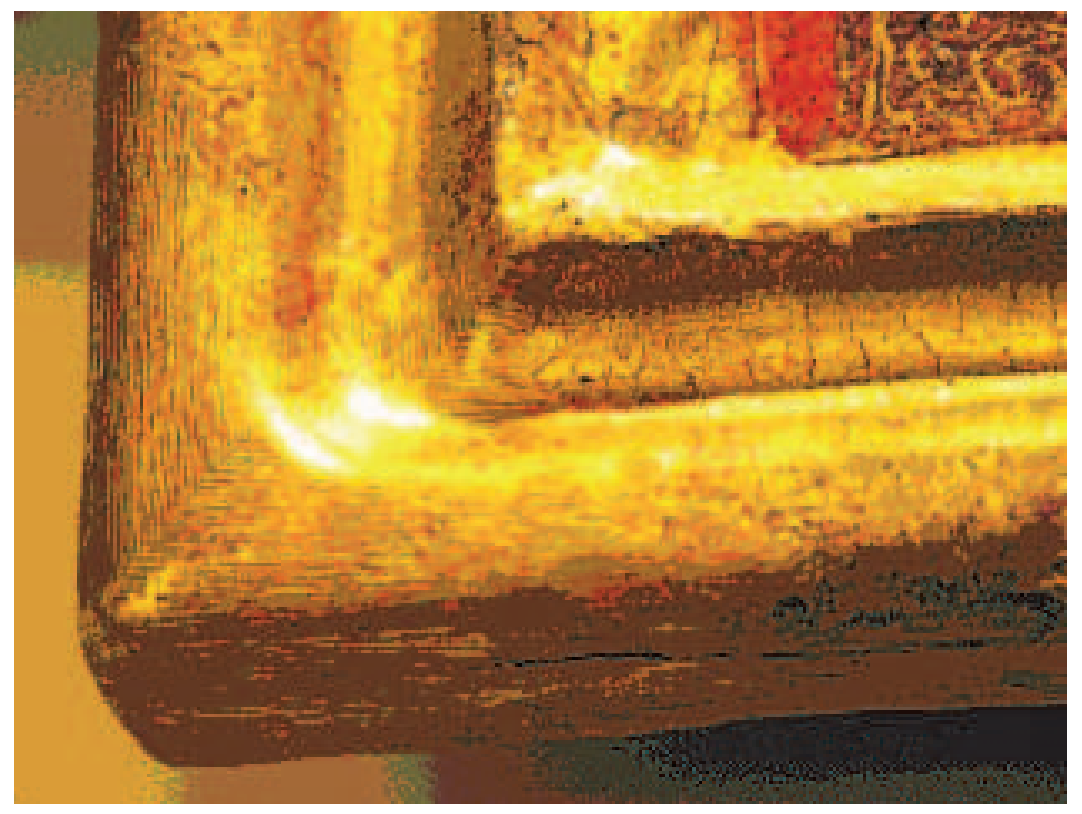

Fot. 6. Retusz „włoski” złoceń uzyskany poprzez pokrycie złotej folii farbami akwarelowymi o różnych kolorach i wypolerowaniu (fot. M. Targowska) 


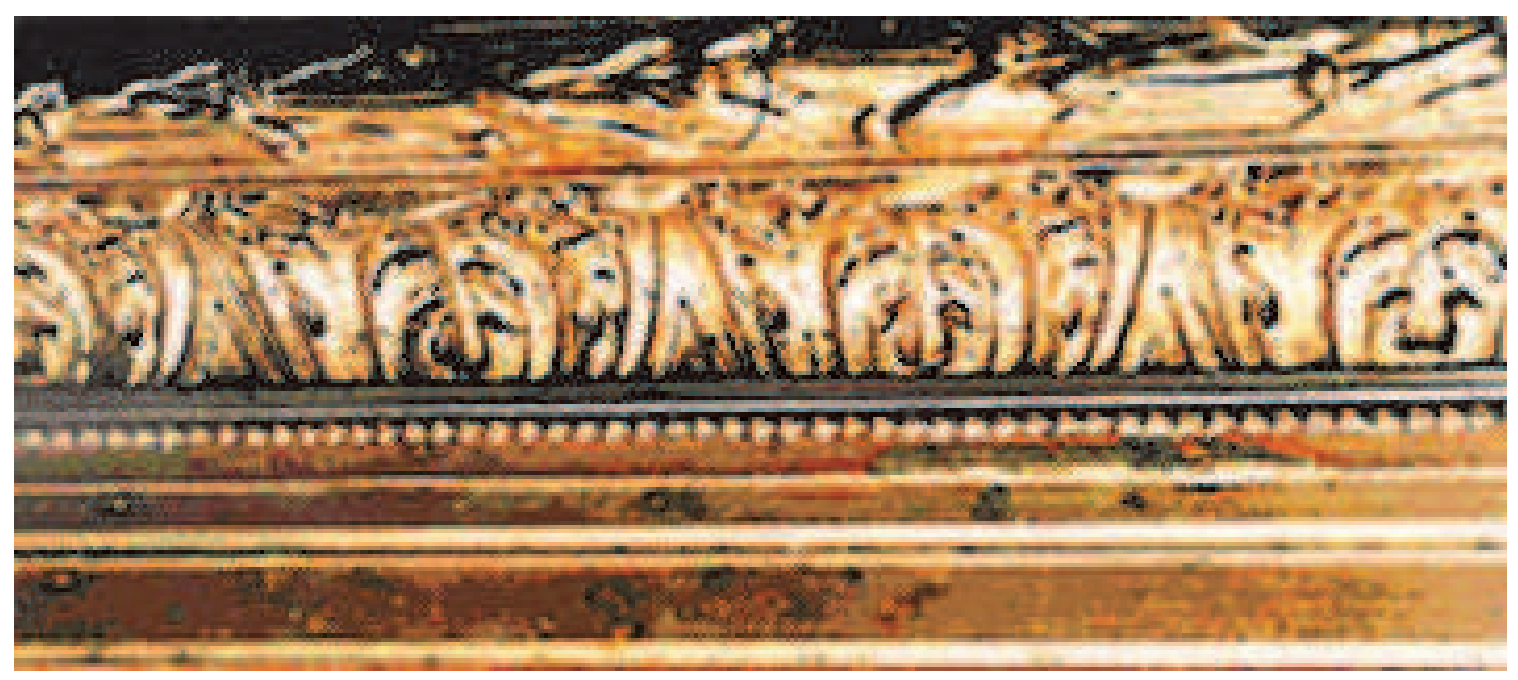

Fot. 7. Retusz zniszczonych płatków szlagmetalu płatkiem nie zawsze daje pożądane rezultaty (fot. K. Wantuch-Jarkiewicz)

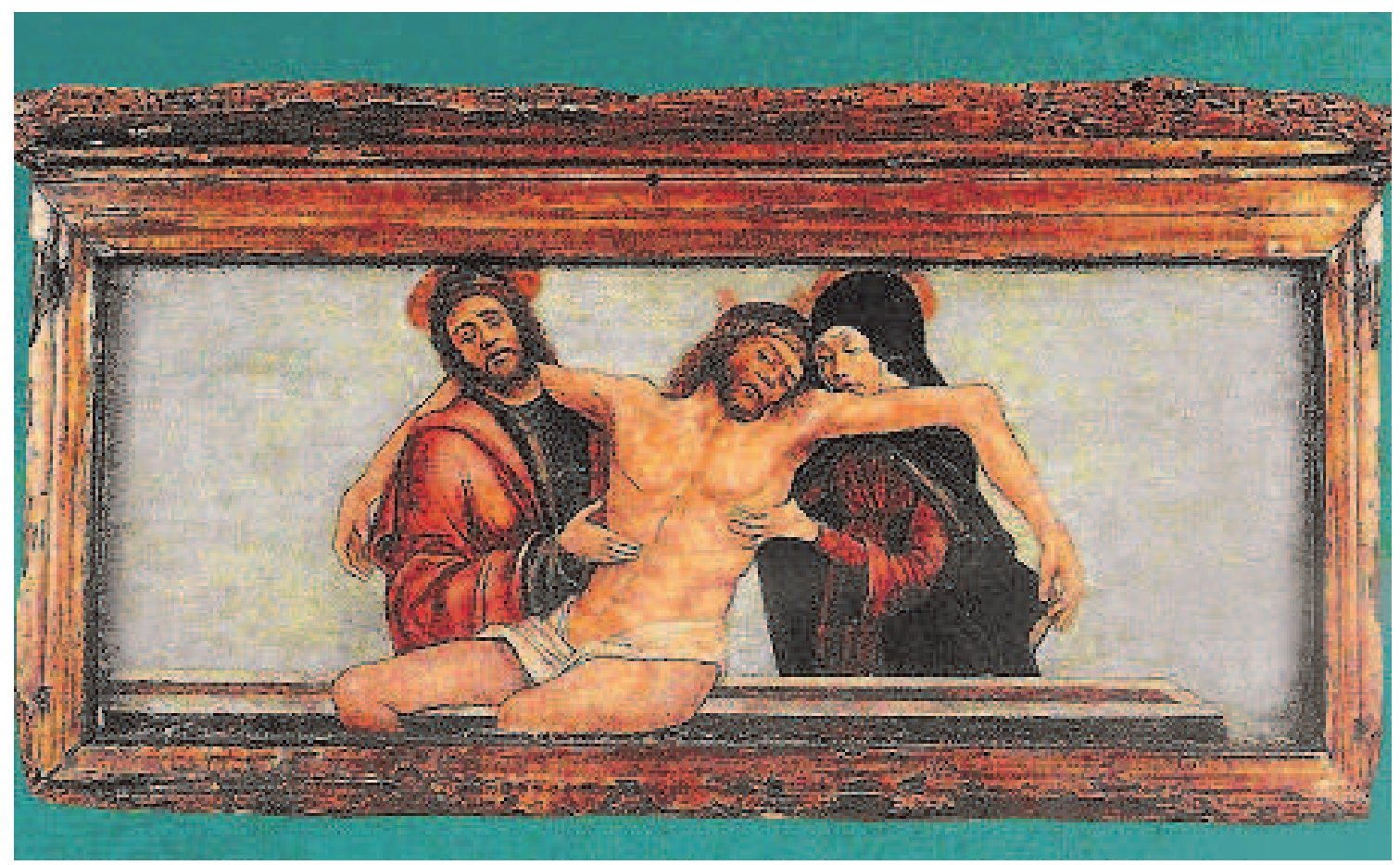

Fot. 8. Włoska rama XVI-wieczna; jej stan zachowania pozwala na ekspozycję bez większych zabiegów estetycznych (reprodukcja) 


\section{Summary}

\section{Conservation and restoration of gilt picture frames surfaces}

Conservation and restoration of gilt picture frames surfaces is not represented very much in the field literature. Is it so perhaps because of the natural continuation of gilding craft rather then conservation goals?

Theoretical and practical bases of conservation and restoration of gilt picture frame surfaces were presented and disscuced. The subject of the discussion is old and worn gilt surfaces. They are worn and neither even in color nor in gloss. These and other matters one should take into account during and before restoring of old gilt surfaces. Both traditional and nontraditional methods were presented by the author. 